\title{
Evidence for circumpolar distribution of planktonic Archaea in the Southern Ocean
}

\author{
Alison E. Murray ${ }^{1}$, Ke Ying Wu ${ }^{1}$, Craig L. Moyer ${ }^{2}$, Dave M. Karl $^{3}$, \\ Edward F. DeLong ${ }^{1, *}$ \\ ${ }^{1}$ Marine Science Institute, University of California, Santa Barbara, California 93106, USA \\ ${ }^{2}$ Biology Department, Western Washington University, Bellingham, Washington 98225, USA \\ ${ }^{3}$ Department of Oceanography, School of Ocean, Earth Science and Technology, University of Hawaii, \\ Honolulu, Hawaii 96822, USA
}

\begin{abstract}
Surveys using rRNA-targeted probes specific for the 3 domains of life (Eucarya, Archaea, and Bacterial indicated the presence, and at times high abundance, of archaeal rRNA in a variety of water masses surrounding Antarctica. Hybridization signals of archaeal rRNA contributed significantly to that of total picoplankton rRNA both north and south of the Polar Front in Drake Passage. Late winter surface water populations collected around the South Shetland Islands also yielded relatively high archaeal rRNA hybridization signals, approaching $10 \%$ or greater of the total rRNA. Summer samples collected in the western region of the Antarctic Peninsula and at McMurdo Sound in the Ross Sea region of Antarctica yielded lower amounts of archaeal rRNA in the surface waters, and higher levels of archaeal rRNA at depth $(150$ to $500 \mathrm{~m}$ ). The hybridization data were compared to biological, chemical, and hydrographic information when possible. In surface waters, archaeal rRNA and chlorophyll a varied inversely. The data presented here further supports the hypothesis that planktonic archaea are a common, widespread and likely ecologically important component of Antarctic picoplankton assemblages. The presence of these archaea in circumpolar deep water suggests a conduit for their circumpolar transport around Antarctica via the Antarctic Circumpolar Current, as well as their export to the deep sea, or to intermediate waters of the South Atlantic via mixing at the polar front.
\end{abstract}

KEY WORDS: Planktonic archaea SSU rRNA hybridization - Antarctica

\section{INTRODUCTION}

The use of oligonucleotide probes targeted to the SSU rRNA of the 3 domains of life (Woese 1990) has facilitated the exploration of microbial diversity in a variety of environments (for example see Stahl et al. 1988, Giovannoni et al. 1990, DeLong 1992, Raskin et al. 1994, Preston et al. 1996, Fry et al. 1997, Lin et al. 1997, Massana et al. 1997). Furthermore, this approach lends itself to quantification when normalized to a universal probe (Raskin et al. 1994, Zheng et al. 1996) and evaluation of the relative contributions of each domain to the system of interest. This approach along with sequencing of rRNA genes has opened the field of

\footnotetext{
- Addressee for correspondence. Present address: Monterey Bay Aquarium Research Institute, PO Box 628, Moss Landing, California 95039, USA. E-mail: delong@mbari.org
}

picoplankton ecology to include the detection of uncultivated prokaryotes, which has been limited to bulk measurements or cultivation based approaches.

Molecular investigations of picoplankton nucleic acid extracts have indicated that the planktonic archaea are indigenous members of temperate coastal oceans (DeLong 1992, Massana et al. 1997) and of deep sea waters (Fuhrman et al. 1992, Fuhrman \& Davis 1997). Recently archaeal nucleic acids were detected in high abundance in the nearshore surface waters off Anvers Island, Antarctica (DeLong et al. 1994). Subsequent studies have extended the ecologiCal analyses of the Archaea in the Anvers Island region (Murray et al. 1998), and described the distribution of the planktonic archaea in the Gerlache Strait, west of the Antarctic Peninsula (Massana et al.1998).

The presence of planktonic archaea in both temperate and Antarctic waters suggests a potential for global 


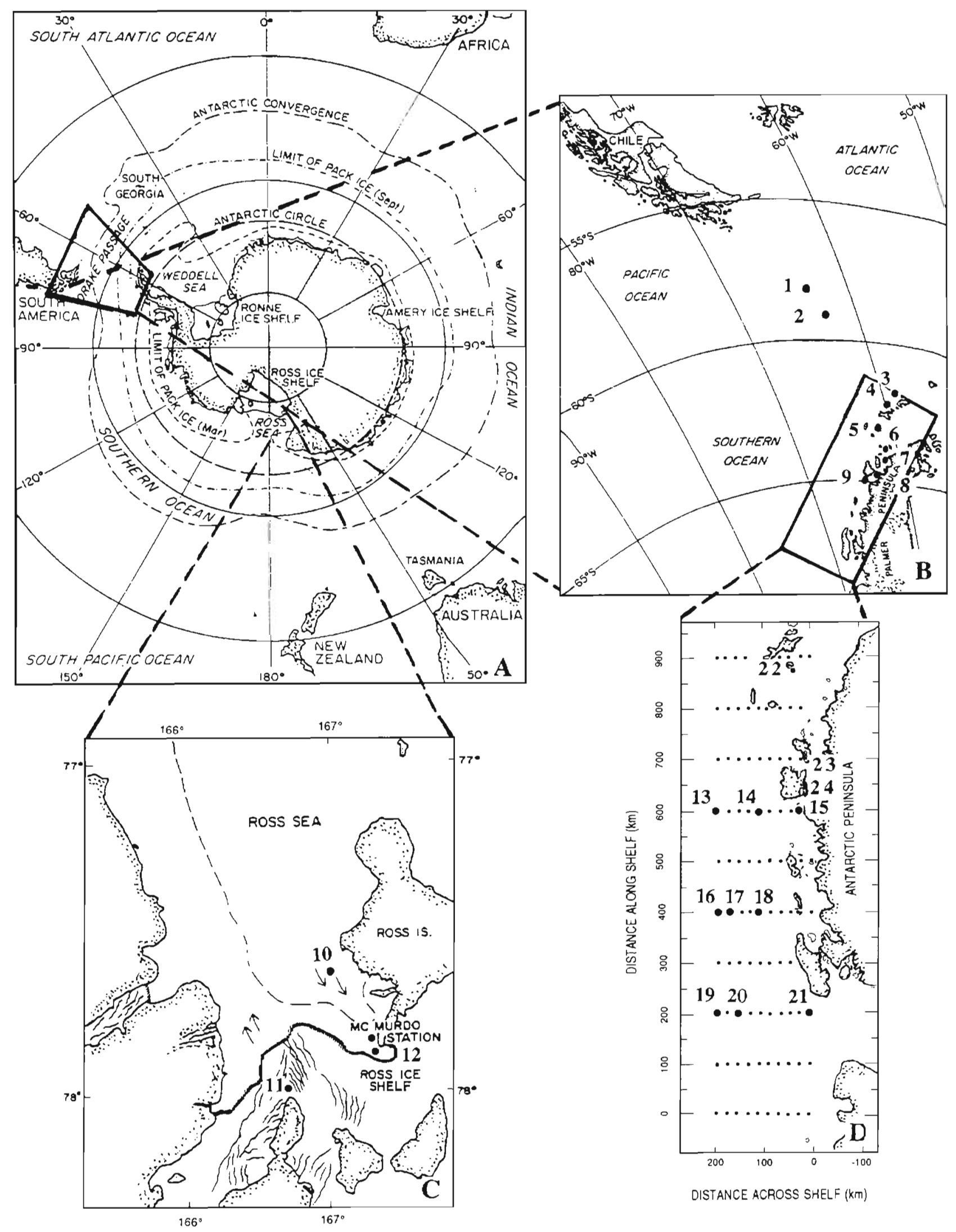


distribution in marine plankton and a biological capability for existing in $-1.5^{\circ} \mathrm{C}$ polar waters. The majority of the planktonic archaeal rRNA sequences form a closely related monophyletic clade in the Crenarchaeota division of the archaea referred to as marine Group I. Recently, other phylogenetic relatives of the marine Group I archaea have been detected in a variety of environments such as in deep sea holothurians (McInerey, et al. 1995), lake sediments (Hershberger, et al. 1996, MacGregor et al. 1997, Schleper et al. 1997), deep sea vents (Moyer et al. in press) and terrestrial soils (Ueda et al. 1995, Bintrim et al. 1997). The other group of planktonic archaea which appear to be less abundant in the plankton, the marine Group II, are affiliated with the euryarchaeota, and have a higher degree of phylogenetic diversity among sequenced representatives. Recent studies have reported sequences phylogenetically related to the marine Group II from marsh sediments (Munson et al. 1997) and from a hydrothermal vent microbial mat system (Moyer et al. in press). However these 'vent' samples and the Group I vent sequences referred to above were convectively mixed with low temperature water (seawater sampled was 15 to $30^{\circ} \mathrm{C}$ ), and contained bacterial types closely related to known psychrophiles, so the source of Group I and Group II archaea detected in these microbial samples might be initially from the surrounding seawater habitat. The physiological lifestyles of the planktonic archaea remain unknown, although the widespread distribution of mesophilic and psychrophilic archaea implies the potential for a variety of metabolic and ecological roles.

The Antarctic marine environment provides a unique study site since the Antarctic Circumpolar Current $(\mathrm{ACC}$ ) has isolated the continent and surrounding waters, and is contiguous around the continental margins of Antarctica. Local flora and fauna display high endemism, resulting from this isolation (Dayton 1990). This environment is suitable as a testing ground for examining the habitat range and distribution of the planktonic archaea. The physical oceanography of the Southern Ocean has several well-defined water masses, fronts, and frontal zones (for detailed descriptions see Sievers \& Nowlin 1984, Hofmann et al. 1996) with substantial mesoscale structure and flow (Hofmann et al. 1996) as well as intense advective features
(Huntley \& Niiler 1995). As a consequence, the distribution of Antarctic plankton has been reported to be strongly influenced by hydrographic properties (Vincent 1988, Stein \& Heywood 1994, Huntley \& Niiler 1995).

To investigate the geographic distribution of the planktonic archaea we surveyed the relative abundance of Archaea in picoplankton samples collected from Drake Passage, the Antarctic Peninsula, and McMurdo Sound using SSU rRNA oligonucleotide probes. We postulate that if the Archaea are present in Antarctic surface water and Circumpolar Deep Water, dispersal will be facilitated by the ACC leading to large scale circumpolar distribution.

\section{METHODS}

Picoplankton collection and hydrographic data acquisition. Sample collections were undertaken in 4 different Antarctic field seasons and locations. From September 15-19, 1995 surface seawater was sampled at 7 stns in the Antarctic Peninsula region between King George and Anvers Island (Fig. 1B). Samples were collected by bucket off the aft deck of the RV 'Polar Duke' (20 to 251 per sample). Seawater samples were processed on board using a method previously described (Murray et al. 1998) in which seawater was filtered through an in-line $1.0 \mu \mathrm{m}$ glass fiber filter (Micron Separations Inc.) then through $0.22 \mu \mathrm{m}$ filter units (Sterivex, Millipore). Lysis buffer $(1.8 \mathrm{ml}, 40 \mathrm{mM}$ EDTA, $50 \mathrm{mM}$ Tris- $\mathrm{HCl}, 0.75 \mathrm{M}$ sucrose) was immediately added to each filter unit. The units were sealed and stored at $-70^{\circ} \mathrm{C}$ until subsequently processed for nucleic acid contents. Bacterioplankton abundance was determined by DAPI staining and epifluorescence microscopy (Porter \& Feig 1980). Chlorophyll a concentrations (Parsons et al. 1984) were determined for each seawater sample as previously described (Murray et al. 1998). Thermosalinograph data were recorded continuously throughout the cruise track; sea surface temperature and salinity were also recorded at each station and sample depth.

Picoplankton samples were collected from hydrocasts at 3 stations on each of the 200,400, and 600 LTER grid lines (total of 9 stations), in Discovery Bay at Deception

Fig. 1. (A) Map of the Antarctica, Southern Ocean, neighboring oceans, seasonal pack ice extent and location of the Antarctic convergence. (B) Drake Passage sampling sites, Stn $1\left(58^{\circ} 09.76^{\prime} \mathrm{S}, 63^{\circ} 38.36^{\prime} \mathrm{W}\right)$ north of the polar front and $\mathrm{Stn} 2\left(59^{\circ} 16.05^{\prime} \mathrm{S}\right.$, $63^{\circ} 12.88^{\prime} \mathrm{W}$ ) south of the polar front. Stns 3 to 9 sampled west of the Antarctic Peninsula (Ant. Pen.) near the South Shetland Islands. (C) McMurdo Sound sample locations, Stn 10 at the ice edge, Stn 11 at the Bratina Island Ice Crack, and Stn 12, 3 miles west of McMurdo Station. The arrows indicate surface current direction and the dashed line indicates the ice edge in January; map modified from Hodson et al. (1981). (D) Location of LTER grid lines, and locations sampled west of the Antarctic Peninsula. Grid lines 200,400, and 600 (Stns 13 to 21) are designated by distance along and across the shelf. Deception Island (Stn 22) and Palmer sampling stations PALB and PALE (Stns 23 and 24) located in the nearshore region of Anvers Island were also sampled 
Island and at Palmer sampling stations PALB and PALE between December 25, 1994 and February 5, 1995 (Fig. 1d). Typically 3 depths were sampled on each hydrocast: surface, midwater $(35$ to $120 \mathrm{~m}$ ) at the base of the mixed layer or at the temperature minimum, and $500 \mathrm{~m}$ when the bottom depth exceeded $500 \mathrm{~m}$ (Stn 400.120 was sampled at $330 \mathrm{~m}$, Deception Island at $150 \mathrm{~m}$, PALB at $60 \mathrm{~m}$, and PALE at $145 \mathrm{~m}$ ). These samples ( 4 to 361 per sample) were processed by filtration through a $202 \mu \mathrm{m}$ mesh nitex screen followed by vacuum filtration onto $0.2 \mu \mathrm{m}$ Supor-200 filters $(47 \mathrm{~mm}$ dia., Gelman Sciences). Filters were folded in half and stored frozen until transport to Santa Barbara, CA, USA, on dry ice for nucleic acid extraction and hybridization experiments. CTD, chlorophyll, nutrient, and bacterial production data were available for these stations from the Palmer LTER data archive on the WWW site (http://www.icess.ucsb.edu/lter).

Samples from McMurdo Sound (25 and $250 \mathrm{~m}$ ) were collected 3 miles west of McMurdo Station, at the Bratina Island ice crack ( 25 and $250 \mathrm{~m}$ ) and at the ice edge $(25 \mathrm{~m}) 20$ miles north of McMurdo Stn by niskin bottle cast in December 1995 (Fig. 1C). In all cases, between 5 and $30 \mathrm{l}$ of seawater was filtered directly onto Sterivex filters using a peristaltic pump. These samples were frozen without the addition of lysis buffer and transported on dry ice to Santa Barbara for nucleic acid extraction.

Hydrocasts in Drake Passage were conducted at stations on either side of the Polar Front in transit to Palmer Stn on July 29, 1996 on the RV 'Polar Duke' (see Fig. $1 \mathrm{~B}$ for station locations). We identified the position of the ship in relation to the polar front by monitoring thermosalinograph data, and examining data from a crossing of Drake Passage a week earlier. Twenty to $30 \mathrm{l}$ of seawater was collected in Go-Flo bottles (10 l capacity, General Oceanics) at depths of 5 . $50,150,350$, and $500 \mathrm{~m}$ at the North Stn, and at depths of $5,50,100,250$, and $500 \mathrm{~m}$ at the South Stn. Samples were processed by filtration through a GF/A glass fiber filter (Whatman) then through a Sterivex filter using a peristaltic pump. Lysis buffer was added to each filter unit, the samples were sealed and frozen at $-70^{\circ} \mathrm{C}$ until nucleic acid extraction. Hydrographic measurements (depth, temperature, salinity, oxygen saturation, in situ fluorescence) were recorded with both casts (Seabird SBE-19 profiler)

Nucleic acid extraction. Nucleic acid extraction has been previously described (Massana et al. 1997, Murray et al. 1998). In brief, lysozyme (1 $\left.\mathrm{mg} \mathrm{ml}^{-1}\right)$ was added to the Sterivex filter units containing $1.8 \mathrm{ml}$ lysis buffer, or to $47 \mathrm{~mm}$ filters which were broken up when frozen in $15 \mathrm{ml}$ conical tubes containing $5 \mathrm{ml}$ lysis buffer. Samples were incubated at $37^{\circ} \mathrm{C}$ for $30 \mathrm{~min}$ then $1 \%$ SDS and freshly prepared proteinase $\mathrm{K}$ $\left(0.5 \mathrm{mg} \mathrm{ml}^{-1}\right)$ were added and incubated at $55^{\circ} \mathrm{C}$ for $2 \mathrm{~h}$. Crude lysates were extracted with phenol:chloroform:isoamylalcohol (25:24:1; pH 8.0), then with chloroform:isoamylalcohol $(24: 1)$. The aqueous phase containing nucleic acids was concentrated and washed with $2 \mathrm{mI} \mathrm{TE} \mathrm{(} \mathrm{pH} 8.0$ ) in microconcentrators (Centricon 100. Amicon), resulting in a final volume of 100 to $200 \mu l$. DNA concentrations were quantified for all extracts with the Hoechst dye assay (modified from method of Paul \& Myers 1982) on a fluorometer (TKO, Hoeffer Scientific).

rRNA oligonucleotide hybridization. The method recently described by Massana et al. (1997) was used to characterize the relative amounts of eucaryal, bacterial and archaeal rRNA in Antarctic picoplankton assemblages. Nucleic acid samples and rRNA controls were applied to nylon membranes (Hybond-N, Amersham) using a slot blotting apparatus. Each blot had 3 to 4 sampies in a 6 - 10 8-fold dilution series starting with 50 to $200 \mathrm{ng}$ DNA in the initial dilution and rRNA controls for each domain in 4-fold dilution series. Ribosomal RNAs from Saccharomyces cervisiae, Escherichia coli or Shewanella putrifaciens, Haloferax volcanii, and Cenarchaeum symbiosum, and rDNAs from an archaeal GII plasmid, OAR22 were used as controls for all experiments. Nucleic acids and $r$ RNAs were denatured in $0.5 \%$ glutaraldehyde/50 $\mathrm{mM} \mathrm{Na}_{2} \mathrm{PO}_{4}$; the plasmid DNA was denatured by boiling for $10 \mathrm{~min}$. Four to 5 replicate blots were prepared for each set of samples. Nucleic acids were UV-crosslinked to the membranes $(120000$ pjoules $\mathrm{cm}^{-2}$, Stratalinker, Strategene). Membranes prehybridized for $30 \mathrm{~min}$ at $45^{\circ} \mathrm{C}$ in hybridization buffer ( 5 to $10 \mathrm{ml}, 0.9 \mathrm{M} \mathrm{NaCl}, 50 \mathrm{mM} \mathrm{Na}_{2} \mathrm{PO}_{4}, 5 \mathrm{mM}$ EDTA, $0.5 \%$ SDS, $10 \times$ Denhardt's solution, $0.5 \mathrm{mg} \mathrm{ml}^{-1}$ polyadenosine), then SSU rRNA probes endlabeled with ${ }^{32} \mathrm{P}$ were added. Table 1 lists the oligonucleotide probes used in these hybridization experiments. Hybridizations ran $>8 \mathrm{~h}$, then blots were washed for $30 \mathrm{~min}$ at room temperature and then for $30 \mathrm{~min}$ at the high stringency wash temperature for each probe (Massana et al. 1997) in pre-warmed wash buffer $1 x$ $\mathrm{SET} / 1 \% \operatorname{SDS}(1 \times \mathrm{SET}: 150 \mathrm{mM} \mathrm{NaCl}, 20 \mathrm{mM}$ Tris$\mathrm{HCl}$ pH 7.8, $2 \mathrm{mM} \mathrm{Na}_{2}$-EDTA). Membrane hybridization signals were quantified with a radioanalytic gas proportional counter (Ambis).

Hybridization signal (HS) of each domain was calculated by (1) determining amount of domain specific probe bound per unit picoplankton rRNA, (2) slopes were multiplied by a probe specific correction factor (universal probe bound per unit control rRNA $x$ domain-specific probe bound per unit control rRNA ${ }^{-1}$ ), (3) corrected slopes were divided by the amount of universal probe bound per unit picoplankton rRNA, and (4) hybridization signals of Archaea, Bacteria and 
Eucarya were expressed as percentages of the universal probe. In all cases the sum of the Archaea, Bacteria and Eucarya probe hybridization signals added up to between 75 and $125 \%$ of the universal probe HS. This variability may be due to quantitative differences in rRNA composition of the samples, as well as systematic errors associated with the methodology. The Group I and Group II archaeal hybridization signals were calculated in the same manner, except that the slopes were multiplied by a group-specific probe correction factor (archaeal probe bound per unit control rRNA $x$ group-specific probe bound per unit control rRNA $^{-1}$ ) then divided by the amount of archaeal probe bound per unit picoplankton rRNA.

\section{RESULTS}

rRNA hybridization studies provided us with the ability to survey a large assortment of picoplankton samples (56 different samples) in order to assess the relative abundance of archaeal rRNA in these picoplankton assemblages. The data presented here are based on the relative binding of Domain or group specific oligonucleotide probes to bulk nucleic acids extracted from mixed microbial populations. It should be noted that any methodology applied to complex, heterogeneous samples has inherent limitations and biases. For example, it will always be difficult to accurately assess lysis and extraction efficiency of uncultivated microorganisms having unknown genome sizes and cell wall compositions. Also, since the hybridization results are relative, absolute increases of decreases in any group remain uncertain. In addition, methodological variations in the collection and storage of some of our samples could have had some influence on the results. Nevertheless, the relative quantities and patterns of archaeal rRNA distribution we report here are consistent with previous reports from other locales, using a variety of different methods (DeLong 1992, Fuhrman et al. 1992, Fuhrman \& Davis 1997. Murray et al. 1998).
We used the universal 1392 probe to normalize our hybridization results in this study, which appears to overestimate the archaeal HS. A report by Zheng et al. (1996) indicated a potential bias using this probe resulting in overestimating the amount of archaeal signal in mixed microbial assemblage samples. We investigated this potential bias by conducting numerous experiments ( $\mathrm{n}=96$; Massana et al. 1998 and $\mathrm{n}>100$; Murray et al. 1998 ). Using our experimental protocol with Antarctic samples, we empirically determined that the universal 1392 probe overestimates the archaeal rRNA hybridization signal by a factor of approximately 2.0 in comparison to the universal 1390 probe. The ratio of the archaeal $\mathrm{HS}_{1392}: \mathrm{HS}_{1390}=1.95 \pm$ $0.5, \mathrm{n}=128$.

\section{rRNA composition of Antarctic Peninsula picoplank- ton assemblages in austral late winter and summer}

Picoplankton assemblages from late winter Antarctic Peninsula surface waters contained 7 to $21 \%$ archaeal rRNA (Ant. Pen. samples, Table 2). The majority of this archaeal signal was attributed to Group I crenarchaeota (averaging $81.6 \%$ of the archaeal HS). Bacteria rRNA dominated most picoplankton samples (averaging $68.5 \%$ for this data set). Total prokaryote counts ranged between 0.9 and $1.6 \times 10^{8}$ cells $l^{-1}$ in the Ant. Pen. samples. Eukaryote rRNA, ranging from 12 to $29 \%$, was moderately low and correlated with the low chlorophyll a concentrations (ranging from 0.1 to $0.23 \mu \mathrm{g} \mathrm{l}^{-1}$ in September) detected in this region during the late winter.

rRNA analysis of picoplankton samples from nearshore stations PALB and PALE in the austral summer (Table 2) indicated an extremely low archaeal rRNA signal in surface waters, in comparison to data collected in late winter-early spring Ant. Pen. samples. The relative proportion of archaea at PALB and PALE did increase with water column depth. This observation corroborates with findings from another study where average archaeal HS values were reported to be

Table 1. Oligonucleotide probe database (OPD) codes and probe sequences used in this study. Probes used in analysis of Antarctic Peninsula surface samples (AP), and the samples collected on the LTER grid (LTER), at McMurdo Sound (MS) and in Drake Passage (DP) are indicated

\begin{tabular}{|c|c|c|c|c|c|c|c|}
\hline ODP code & Sequence $\left(5^{\prime}-3^{\prime}\right)$ & $\begin{array}{c}\text { Wash temp. } \\
\left({ }^{\circ} \mathrm{C}\right)\end{array}$ & Source & AP & LTER & MS & DP \\
\hline S- - Univ-1392-a-A-15 & ACGGGCGGTGTGTRC & 37 & Pace et al. (1986) & + & + & + & + \\
\hline S-D-Euca-1209-a-A-16 & GGGCATCACAGACCTG & 37 & Giovannoni et al. (1988) & + & + & + & + \\
\hline S-D-Arch-0915-a-A-20 & GTGCTCCCCCGCCAATTCCT & 56 & Amann et al. (1990b) & + & + & + & + \\
\hline S-D-Bact-0338-a-A-18 & GCTGCCTCCCGTAGGAGT & 45 & Amann et al. $(1990 a)$ & + & + & + & + \\
\hline S-O-Cenar-0554-a-A-20 & TTAGGCCCAATAATCMTCCT & 40 & Massana et al. (1997) & + & & & + \\
\hline S-O-ArGII-0554-a-A-20 & TTAGGCCCAATAAAAKCGAG & 40 & Massana et al. (1997) & + & & & + \\
\hline
\end{tabular}


Table 2. Relative abundance and distribution of picoplankton rRNA in waters of the Antarctic Peninsula and McMurcto Sound

\begin{tabular}{|c|c|c|c|c|c|}
\hline \multirow{2}{*}{ Location } & \multirow{2}{*}{ Date } & \multirow[t]{2}{*}{ SW fraction } & \multicolumn{3}{|c|}{ rRNA HS $\mathrm{H}_{1392}(\%)$} \\
\hline & & & Archaea $^{a}$ & Bacteria & Eucarya \\
\hline \multicolumn{6}{|l|}{ Austral winter } \\
\hline Ant. Pen. 3 & 15 Sep 95 & $<1.0 \mu \mathrm{m}$ & 11.5 & 77.6 & 28.6 \\
\hline Ant. Pen. 4 & 16 Sep 95 & $<1.0 \mu \mathrm{m}$ & 14.6 & 85.7 & 12.8 \\
\hline Ant. Pen. 5 & 17 Sep 95 & $<1.0 \mu \mathrm{m}$ & 16.4 & 47.4 & 11.9 \\
\hline Ant. Pen. 6 & $18 \mathrm{Sep} 95$ & $<1.0 \mu \mathrm{m}$ & 17.2 & 96.8 & 14.9 \\
\hline Ant. Pen. 7 & 19 Sep 95 & $<1.0 \mu \mathrm{m}$ & 20.8 & 64.6 & 19.1 \\
\hline Ant. Pen. 8 & $19 \operatorname{Sep} 95$ & $<1.0 \mu \mathrm{m}$ & 12.7 & 60.1 & 23.5 \\
\hline Ant. Pen. 9 & 19 Sep 95 & $<1.0 \mu \mathrm{m}$ & 6.9 & 70.4 & 21.1 \\
\hline PALB surface & 13 Sep 96 & $<1.6 \mu \mathrm{m}$ & 34 & 56.4 & 22.6 \\
\hline PALB $50 \mathrm{~m}$ & $13 \operatorname{Sep} 96$ & $<1.6 \mu \mathrm{m}$ & 35.6 & 57.8 & 16.2 \\
\hline \multicolumn{6}{|l|}{ Austral summer } \\
\hline PALB surface & $\operatorname{Jan} 95$ & Whole water & 0.4 & 35.5 & 87 \\
\hline PALB $60 \mathrm{~m}$ & $\operatorname{San} 95$ & Whole water & 38 & 69 & 41.8 \\
\hline PALE surface & $\operatorname{Jan} 95$ & Whole water & 0.4 & 19.2 & 84.9 \\
\hline PALE 35 m & Jan 95 & Whole water & 1.3 & 20.6 & 82 \\
\hline PALE $145 \mathrm{~m}$ & $\operatorname{Jan} .95$ & Whole water & 12.8 & 41.9 & 56.7 \\
\hline Deception $5 \mathrm{~m}$ & $24 \mathrm{Dec} 94$ & Whole water & 0.2 & 28.4 & 71.7 \\
\hline Deception $50 \mathrm{~m}$ & 24 Dec 94 & Whole water & 0.6 & 28.5 & 79.5 \\
\hline Deception $150 \mathrm{~m}$ & 24 Dec 94 & Whole water & 7.8 & 55.4 & 44.7 \\
\hline Bratina Crack 25 m & 9 Dec 95 & Whole water & 0.9 & 84.1 & 10.2 \\
\hline Bratina Crack $250 \mathrm{~m}$ & 14 Dec 95 & Whole water & 9.6 & 36.7 & 31.7 \\
\hline
\end{tabular}

$2.3 \pm 2.4$ for the austral summer (Murray et al. 1998). It appears that regardless of size fraction investigated (whole water in this study, and $<1.6 \mu \mathrm{m}$ fraction in the Murray et al. 1998 study) the archaeal rRNA constitutes a minimal proportion of the picoplankton rRNA in austral summer surface waters. Size fractionation experiments conducted during late winter in the Gerlache Strait (Massana et al. 1998) indicated that the relative percent of archaea increased 2- to 5 -fold between the whole water and the 0.2 to $0.8 \mu \mathrm{m}$ size fraction. This suggests that there are differences in relative abundance hybridization data depending on the size fraction collected. For Antarctic summer surface samples this difference was small, between 0.4 and approx. $2.3 \%$. Samples from Whaler's Bay, Deception Island, displayed a similar pattern of extremely low archaeal HS in the surface waters, increasing to $7.8 \%$ at $150 \mathrm{~m}$

Spring-summer samples collected at LTER grid stations also showed relatively low archaeal rRNA HS in surface waters averaging 1.0 (SD 1.4, $n=8$, Fig. 2). Subsurface samples collected at depths between 75 and $150 \mathrm{~m}$ (below the chlorophyll max.) also indicated low archaeal hybridization signals at 6 out of 8 stations (average $0.9 ; \mathrm{SD} 0.5, \mathrm{n}=6$ ). Significant variation in the archaeal HS was found at the mid-water depths on the 200 grid line $(60$ to $120 \mathrm{~m}$ ), where values of 7.6 and 10.8 were much higher than the average for the other samples. In most of the deep profiles (to 300 or $500 \mathrm{~m}$ ), archaeal rRNA hybridization signals were the highest values detected in each profile, averaging 8.0 (SD 3.5, $n=9)$.

Evaluation of water column hydrographic, chemical and biological data corresponding to these casts suggests the following general trends. (1) Density profiles indicated a mixed layer depths between 8 and $35 \mathrm{~m}$; in all cases the archaeal HS was very low in the mixed layer. The mid-water samples were collected at the temperature minimum, which generally corresponded to the pycnocline (Fig. 3A). No consistent trends between the mid-water archaeal HS and depth, or intensity of the pycnocline was observed. (2) Depths of the chlorophyll a maximum (>0.5 $\mu \mathrm{g} \mathrm{l}^{-1}$ ) were near $50 \mathrm{~m}$ at outer and mid-line stations, and at $100 \mathrm{~m}$ at inshore stations on the 400 and 200 lines (Fig. 3B). Archaeal rRNA hybridization signals were never over $4 \%$ in any case where the chlorophyll concentration was $>0.5 \mu \mathrm{g} \mathrm{I}^{-1}$. Correlation analysis suggested that there was a significant negative relationship between chlorophyll a concentration and archaeal rRNA HS ( $r$ $=-0.39, \mathrm{p}<0.05, \mathrm{n}=25$ ), and that there was a positive relationship between eucaryl rRNA and chlorophyll concentration $(\mathrm{r}=0.46, \mathrm{p}<0.02, \mathrm{n}=25)$. The 200.000 stn had a high chlorophyll a concentration above $115 \mathrm{~m}$ averaging $4.2 \mu \mathrm{g} \mathrm{I^{-1 }}$, which is typical of that station. The archaeal HS was moderately high (12\%) below the chlorophyll maximum at the same station. (3) Bacterial production measured by leucine incorpo- 

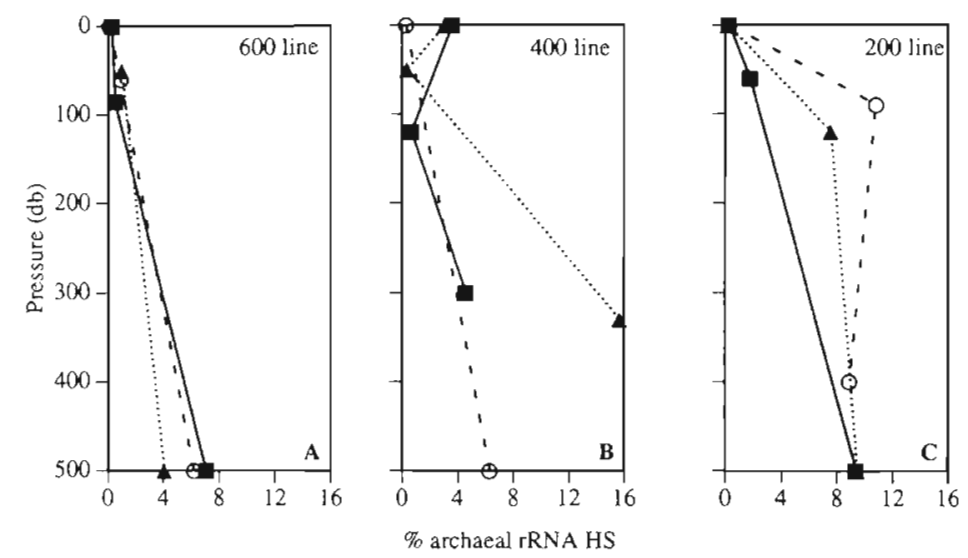

Fig. 2. Profiles of archaeal rRNA $H_{1392}$ at LTER stations collected in austral summer 1994-95. Profiles collected on the same grid-line are plotted together. (- Offshore Stns 600.200, 400.200, and 200.200. (O---O)

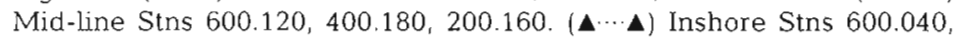
400.120, and 200.000. ( HS $_{1392}$ may overestimate actual HS values by approximately 2-fold. See results, Massana et al. 1998, and Murray et al. 1998)

ration (data not shown) indicated that the majority of the activity on the 600 line was in the upper $50 \mathrm{~m}$, where the corresponding archaeal HS was minimal. (4) Nitrate concentrations on the 600 grid line (data not shown) were generally high with values in the upper $50 \mathrm{~m}$ between 26 and $30 \mu \mathrm{M}$ increasing to 28-33 $\mu \mathrm{M}$ below $75 \mathrm{~m}$. Outer and mid stations on the 200 grid line were similar with nitrate concentrations of $24 \mu \mathrm{M}$ in the upper $50 \mathrm{~m}$ increasing to $33 \mu \mathrm{M}$ below $100 \mathrm{~m}$. The $200.000 \mathrm{stn}$ surface waters (upper $100 \mathrm{~m}$ ) were lower in nitrate (19 to $23 \mu \mathrm{M})$ in correspondence with the high phytoplankton abundances found there (as indicated by chlorophyll a concentrations).
Archaeal rRNA was detected in all (7) samples collected in the McMurdo Sound region. Samples collected offshore of Bratina Island showed higher rRNA abundances at depth than in the surface waters (Table 2), which is similar to the trends seen in surface waters on the other side of the continent. Other samples collected off Bratina Island $(500 \mathrm{~m})$, in McMurdo Sound ( $25 \mathrm{~m}$ and $250 \mathrm{~m}$ ), as well as at the ice edge $(25 \mathrm{~m})$ all indicated the presence of archaea, though these samples were not quantified.

\section{Presence of archaeal rRNA in McMurdo Sound}

\section{Archaeal rRNA distribution in water masses north and south of the Polar Front}

Sampling at the frontal boundary of Subantarctic and Antarctic waters in Drake Passage (Fig. 4A) indicated high abundance of archaeal rRNA throughout the water column. Although the hydrographic characters were completely different on either side of the Polar Front (PF), archaeal HS showed similar patterns with depth. Subsurface maxima in both archaeal rRNA profiles were found at the thermocline on either side of the PF (100 and 150 m, Figs. 4B,C). Hybridization analyses with the Group I and Group II archaeal probes suggested that crenarchaeal Group I archaea accounted for an average of $93.4 \%$ of the archaeal signal, while the Group II HS was only $2.9 \%$ of the archaeal HS for the Drake Passage samples. Surface eucaryal rRNA constituted 20 and $50 \%$ of the hybridization signal in the $<1.6 \mu \mathrm{m}$ seawater fraction north and south of the PF respectively. The eukaryote rRNA dropped off in both casts to $<5 \%$ below $150 \mathrm{~m}$. Fluorescence maxima at $15 \mathrm{~m}$ on the north side of the front and at $75 \mathrm{~m}$ on the south side did not correspond to the eukaryote rRNA signal.

Further evidence of the discrete differences in water mass characteristics is clear upon comparison of the temperature-salinity (T-S) diagrams from both casts (Fig. 5A). The T-S space occupied by these data are consistent with those reported for Antarctic Surface, Subantarctic Surface, and Circumpolar Deep Water masses (ASW, SASW, and CDW respectively) described by Whitworth (1980). The nearly isohaline salinity pro-
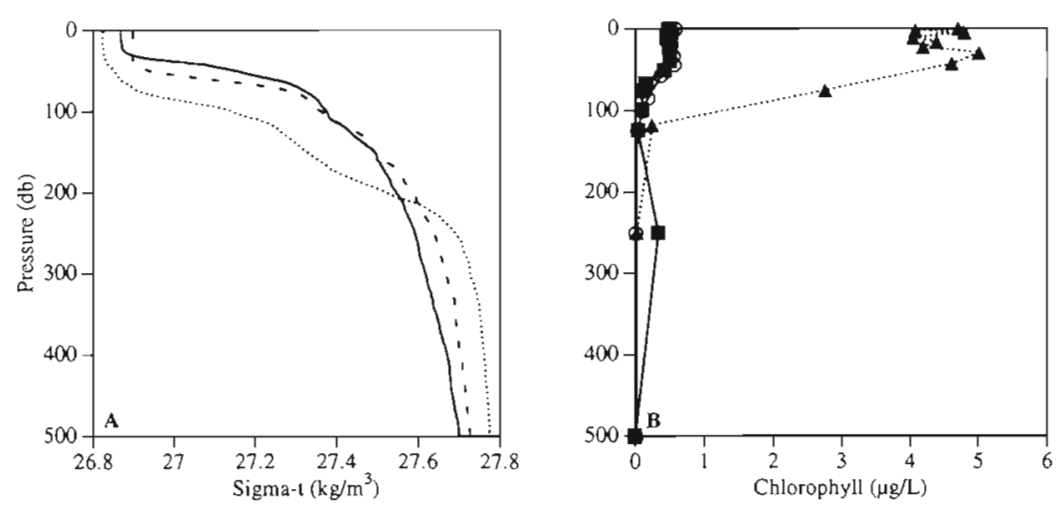

Fig. 3. (A) Sigma-t profiles on the LTER grid 200 line. Samples were collected at the surface, mid-water sample depths of 60, 90, and $120 \mathrm{~m}$ for Strns 200.200, 200.160 , and 200.000 respectively, and at $500 \mathrm{~m}$. Solid line corresponds to the cast at $\operatorname{Stn} 200.200$; dashed line corresponds to Stn 200.160, and dotted line corresponds to Stn 200.000 . (B) Chlorophyll a concentrations at the same sampling stations as in (A). Symbols and lines as in Fig. 2 

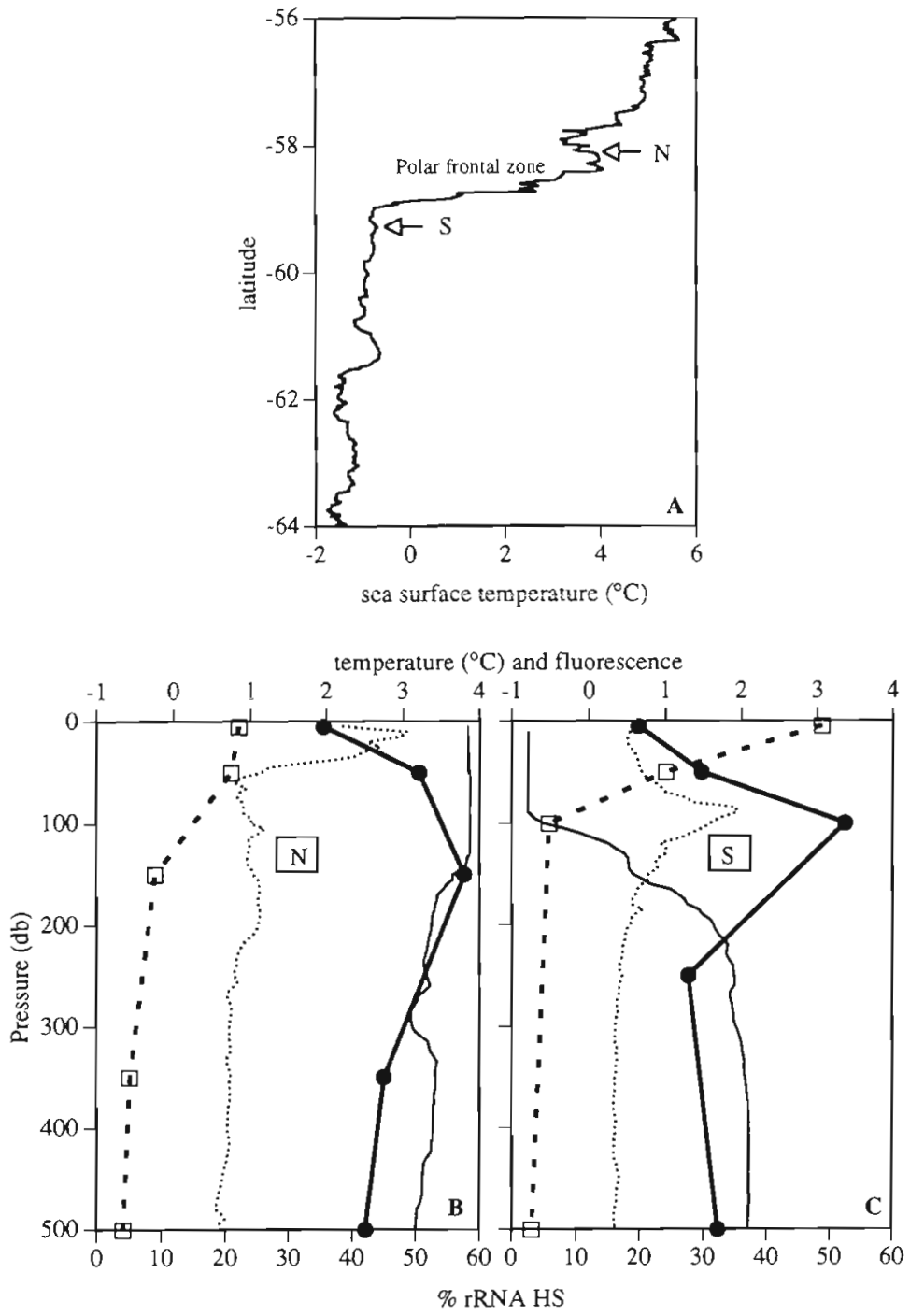

Fig. 4. Drake Passage hydrocasts were performed at stns north $(\mathrm{N})$ and south (S) of the polar front (A). Distribution of archaeal ( ) and eucaryal (D) rRNA $\mathrm{HS}_{1392} \mathrm{~N}(\mathrm{~B})$ and $\mathrm{S}$ (C) of the polar front. Temperature profiles shown with solid line, in situ fluorescence (arbitrary units) shown with dotted line. $\left(\mathrm{HS}_{1392}\right.$ may overestimate actual HS values by approximately

2 -fold. See results, Massana et al. (1998), and Murray et al. (1998))

file north of the PF (Fig. 5B) is indicative of SASW above $300 \mathrm{~m}$. Below this an inflection in the salinity profile at $300 \mathrm{~m}$ indicates the upper region of Antarctic Intermediate Water, which is a mixture of ASW, and SASW characterized by a salinity minimum, densities (sigma) of 27.25 to $27.35 \mathrm{~kg} \mathrm{~m}^{-3}$, cold waters, and nutrients representative of the ASW (Sievers \& Nowlin 1984). South of the PF, the salinity profile clearly shows the differences between ASW (mixed isohaline layer in the upper $100 \mathrm{~m}$ ) and CDW ( $\mathrm{T}>1.0^{\circ} \mathrm{C}$, Fig. $4 \mathrm{C}$; salinity maxima, Fig. 5B) described by Sievers \& Nowlin (1984). Oxygen profiles (data not shown) also corroborate with these observations. The ASW was saturated with oxy-
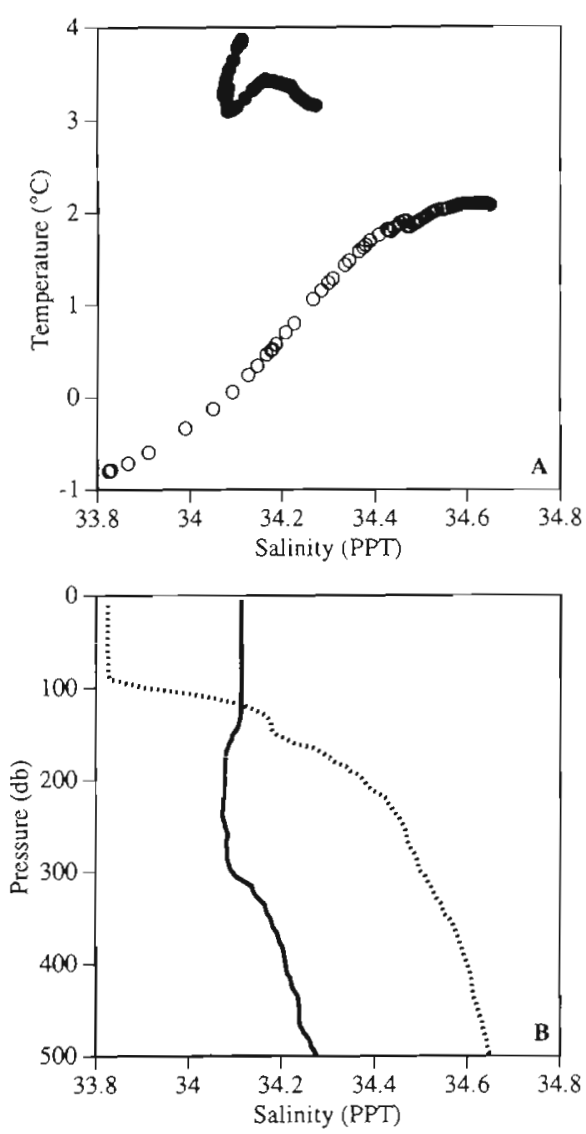

Fig. 5. Hydrographic characteristics of Drake Passage water masses north and south of the Polar Front July 29, 1996. (A) T-S diagram of (-) north and (O) south profiles. (B) Salinity profiles in Drake Passage where the solid line displays salinity of the north cast and dotted line corresponds to the south cast

gen ( $\left.360 \mu \mathrm{mol} \mathrm{kg}{ }^{-1}\right)$ below which the underlying CDW displayed a characteristic $\mathrm{O}_{2}$ minimum (333 $\mu$ mol $\mathrm{kg}^{-1}$ at $250 \mathrm{~m}$ ). The SASW was lower in oxygen ( $315 \mu \mathrm{mol} \mathrm{kg} \mathrm{kg}^{-1}$ ), having a weak subsurface maxima at $285 \mathrm{~m}$ (324 $\mu \mathrm{mol} \mathrm{kg}^{-1}$ ).

\section{DISCUSSION}

SSU rRNA targeted oligonucleotide hybridization studies have enabled us to assess the relative contribution of Archaea, Bacteria and Eucarya in Antarctic marine picoplankton assemblages. This approach is particularly suitable for studies of the planktonic archaea, since they appear to be comprised predominantly of only 2 divergent phylogenetic groups. The Antarctic archaeal planktonic assemblage is predominantly comprised of the Group I phylotypes as shown 
in this study and others (DeLong et al. 1998, Massana et al. 1998, Murray et al. 1998). Hence, despite the fact that we have used probes directed at the domain level for the majority of this work, our study has focused on the distribution of a phylogenetically restricted group of organisms.

In total, our findings indicate that the planktonic archaea may have circumpolar distribution in Antarctic waters. This extends previous observations of planktonic archaea off Palmer station (DeLong et al. 1994, Murray et al. 1998) and in the Gerlache Strait (Massana et al. 1998), suggesting that the archaea are resident organisms of nearshore Antarctic waters. The data presented here indicate that archaeal distribution extends into the Antarctic surface, Subantarctic surface and Circumpolar Deep waters of the Southern Ocean (including those of the Ross Sea).

Transport by the circumpolar current, the largest known current system in the world's ocean (Vincent 1988), is likely an efficient mechanism of dispersal, and maintenance of widely distributed plankton assemblages. There is also potential for transport of planktonic archaea to the deep sea in areas of deep water formation or to Atlantic and Pacific Ocean basins via intermediate water masses. Smaller mesoscale advective features have been shown to be important in plankton transport and population dispersal as indicated by Lagrangian drifter experiments originating in the Gerlache Strait (Huntley \& Niiler 1995). Although physical transport by currents may be a effective means of dispersal, the relative abundances and distributions of picoplankton in different water masses might be representative of those water masses, as reported by Holm-Hansen et al. (1997) in a study in which differences in phytoplankton distribution and abundance could be correlated with different water masses.

The presence of planktonic archaea in McMurdo Sound demonstrates the extensive regional and probably global distribution of these planktonic organisms. The waters of eastern McMurdo Sound originate from the Ross Sea, where the conditions are biologically productive in comparison to the waters in the western sound (sampled at the Bratina Ice Crack), where the water is advected from under the Ross Ice Shelf (Hodson et al. 1981). Depending on sampling location in McMurdo Sound (eastern vs western sound), microbial productivity (Fuhrman \& Azam 1980), and uptake of DOM (Hodson et al. 1981) have been reported to be typical of temperate and deep sea environments respectively. At the time of sample collection there were Phaeocystis blooms in the surface waters of the Bratina Island ice crack (DeVries pers. comm.) with corresponding low archaeal rRNA. At $250 \mathrm{~m}$ the archaeal HS was significant, implying that archaeal populations might be sustained under the Ross Ice Shelf, the likely source of deep water at this location.

Collectively, our data strongly suggests that the Group I archaea are common, widely distributed Antarctic picoplankton constituents. Rather than showing a uniform distribution, it appears that the planktonic archaea vary temporally and spatially in Antarctic waters. A decrease in the archaeal signal between late winter and summer in the surface waters was evident in the Antarctic Peninsula picoplankton samples. This observation is in agreement with a more comprehensive study of temporal variation at stations PALB and PALN (Murray et al. 1998). Archaeal rRNA signal increased with depth in austral summer profiles examined from the LTER grid, at Whaler's Bay and at McMurdo Sound. Whether these observations are a result of the relative nature of these data (i.e. a result of relative increases in eukaryal or bacterial biomass) or whether archaea increase in absolute cell number requires further testing.

The observation of subsurface maxima in Antarctic archaeal rRNA distribution directly below the thermocline (Drake Passage, this study; Palmer Basin, Murray et al. 1998; several profiles in the Gerlache Strait, Massana et al. 1998) provides relevant information regarding their ecology, and suggests that their abundance and biological activity is variable in different strata in the water column. This location in the water column is an active region of particulate organic matter remineralization (Libes 1992). The chemical environment at this location in the water column is rich in inorganic nutrients, and from a biological perspective, there may be less competition for resources (at least between primary and secondary producers) than in the photic zone. There could also be specific biotic interactions between other planktonic bacteria and the archaea. Other studies (Gordon \& Giovannoni 1996) have reported on the distribution of an uncultivated bacteria, SAR406, which also peaks below the chlorophyll max. Some marine nitrifying bacteria also have a well characterized maxima below the thermocline (Ward 1984).

This report has provided more extensive information on the spatial and temporal distribution of planktonic archaea in the Southern Ocean. The significance of their ubiquity and abundance, contribution to total microbial activity, remineralization capabilities, and potential as food resources for predator populations still remain speculative, although their dominance in certain Antarctic oceanic habitats suggests that they might play a significant role in each of these ecological functions. Survival in the pelagic environment requires adaptive capabilities that confer resistance to viral attack, growth rates sufficient to balance removal by grazing, and the ability to survive nutrient and light 
variability encountered in seasonal cycles. The strong seasonal fluctuation of planktonic archaeal distribution in Antarctic surface waters indicates susceptibility to at least one of these environmental variables. Their high abundance in the Southern Ocean, as well as in subsurface temperate waters, confirms that planktonic archaea have adapted well to a planktonic niche which is globally distributed, and suggests that these microorganisms influence the biology and chemistry of this habitat significantly.

Acknowledgements. We thank the captain and crew of the RV 'Polar Duke', and the ASA personal at Palmer Station for excellent support throughout our field program. Special appreciation is extended to Arthur DeVries and Jocelyn Turnbull for collection of the McMurdo samples. This work was supported by National Science Foundation Grants OPP 9418442 and OCE 952984 awarded to E.F.D and OPP 9632763 awarded to D.M.K.

\section{LITERATURE CITED}

Amann RI, Binder BJ, Olson RJ, Chisholm SW, Devereux R, Stahl DA (1990a) Combination of $16 \mathrm{~S}$ rRNA-targeted oligonucleotide probes with flow cytometry for analyzing mixed microbial populations. Appl Environ Microbiol 56: $1919-1925$

Amann RI, Krumholz L, Stahl DA (1990b) Fluorescentoligonucleotide probing of whole cells for determinative, phylogenetic, and environmental studies in microbiology. $J$ Bacteriol 172:762-770

Bintrim SB, Donohue TJ, Handelsman J, Roberts GP, Goodman RM (1997) Molecular phylogeny of Archaea from soil. Proc Natl Acad Sci USA 94:277-282

Dayton PK (1990) Polar Benthos. In: Smith WO (ed) Polar oceanography Part b: chemistry, biology, geology. Academic Press, San Diego, p 632-685

DeLong EF (1992) Archaea in coastal marine environments. Proc Natl Acad Sci 89:5685-5689

DeLong EF, Wu KY, Prezelin BB, Jovine RVM (1994) High abundance of Archaea in Antarctic marine picoplankton. Nature 371:695-697

DeLong EF, King LL, Massana $R$, Cittone $H$, Murray AE, Schleper C, Wakeham SG (1998) Cyclic and acyclic dibiphytanyl ether lipids in marine psychrophilic crenarchaeotes: evolutionary and ecological implications. Appl Environ Microbiol 64:1133-1138

Fry NK, Fredrickson JK, Fishbain S, Wagner M, Stahl DA (1997) Population structure of microbial communities associated with two deep, anaerobic, alkaline aquifers. Appl Environ Microbiol 63:1498-1504

Fuhrman JA, Azam F (1980) Bacterioplankton secondary production estimates for coastal waters of British Columbia, Antarctica, and California. Appl Environ Microbiol 39: $1085-1095$

Fuhrman JA, Davis AA (1997) Widespread archaea and novel bacteria from the deep sea as shown by $16 \mathrm{~S}$ rRNA gene sequences. Mar Ecol Prog Ser 150:275-285

Fuhrman JA, McCallum K, Davis AA (1992) Novel major archaebacterial group from marine plankton Nature 356 : $148-149$

Giovannoni SJ, DeLong EF, Olsen GJ, Pace NR (1988) Phylogenetic groupspecific oligodeoxynucleotide probes for identification of single microbial cells. J Bacteriol 170; $720-726$

Giovannoni SJ, Britschgi TB, Moyer CL, Field KG (1990) Genetic diversity in Sargasso Sea bacterioplankton. Nature 345:60-63

Gordon DA, Giovannoni SJ (1996) Detection of stratified microbial populations related to Chlorobium and Fibrobacter species in the Atlantic and Pacific oceans. Appl Environ Microbiol 62:1171-1177

Hershberger KL, Barns SM, Reysenbach AL (1996) Wide diversity of Crenarchaeota. Nature 384:420

Hodson RE, Azam F, Carlucci AF, Fuhrman JA, Karl DM, Holm-Hansen O (1981) Microbial uptake of dissolved organic matter in McMurdo Sound, Antarctica. Mar Biol 61:89-94

Hofmann EE, Klinck JM, Lascara CM, Smith DA (1996) Water mass distribution and circulation west of the Antarctic Peninsula and including Bransfield Strait. In: Foundations for ecological research west of the Antarctic Peninsula. AGU, 70 p 61-80

Holm-Hansen $O$, Hewes CD, Villafane VE, Helbling EW, Silva N, Amos T (1997) Distribution of phytoplankton and nutrients in relation to different water masses in the area around Elephant Island, Antarctica. Polar Biol 18: $145-153$

Huntley ME, Niller PP (1995) Physical control of population dynamics in the Southern Ocean. ICES J Mar Sci 52: $457-468$

Libes S (1992) An introduction to marine biogeochemistry. Wiley, New York

Lin C, Raskin L, Stahl DA (1997) Microbial community structure in gastrointestinal tracts of domestic animals: comparative analyses using rRNA targeted oligonucleotide probes. FEMS Microbiol Ecol 22:281-294

MacGregor BJ, Moser DP, Alm EW, Nealson KH, Stahl DA (1997) Crenarchaeota in Lake Michigan sediment. Appl Environ Microbiol 63:1178-1181

Massana R, Murray AE, Preston CM, DeLong EF (1997) Vertical distribution and phylogenetic characterization of marine planktonic Archaea in the Santa Barbara Channel. Appl Environ Microbiol 63:50-56

Massana R, Taylor LT, Murray AE, Wu KY, Jeffrey WH, DeLong EF (1998) Distribution of marine planktonic archaea in the Gerlache strait, Antarctic Peninsula, during early spring. Limnol Oceanogr (in press)

McInerey JO, Wilkinson M, Patching JW, Embley TM, Powell R (1995) Recovery and phylogenetic analysis of novel archaeal rRNA sequences from a deepsea deposit feeder. Appl Environ Microbiol 61:1646-1648

Moyer CL, Tiedje JM, Dobbs FC, Karl DM (1999) Diversity of deepsea hydrothermal vent Archaea from Loihi Seamount, Hawaii. Deep-Sea Res (in press)

Munson MA, Nedwell DB, Embley TM (1997) Phylogenetic diversity of Archaea in sediment samples from a coastal salt marsh. Appl Environ Microbiol 63:4729-4733

Murray AE, Preston CM, Massana R, Taylor LT, Blakis A, Wu K, DeLong EF (1998) Seasonal and spatial variability of bacterial and archaeal assemblages in the coastal waters off Anvers Island, Antarctica. Appl Environ Microbiol 64: 2585-2595

Pace NR, Stahl DA, Lane DJ, Olsen GJ (1986) The analysis of natural microbial populations by ribosomal RNA sequences. Adv Microb Ecol 9:1-55

Parsons TR, Maita Y, Lalli CM (1984) A manual of chemical and biological methods for seawater analysis. Pergamon Press, New York

Paul JH, Myers B (1982) Fluorometeric determination of DNA 
in aquatic microorganisms by use of Hoechst 33258. Appl Environ Microbiol 43:1393-1399

Porter KG, Feig YS (1980) The use of DAPI for identifying and counting aquatic microflora. Limnol Oceanogr 25: 943-948

Preston CM, Wu KY, Molinski TF, DeLong EF (1996) A psychrophilic crenarchaeon inhabits a marine sponge: cenarchaeum symbiosum gen. nov., sp. nov. Proc Natl Acad Sci 93:6241-6246

Raskin L, Stomley JM, Rittman BE, Stahl DA (1994) Groupspecific $16 \mathrm{~S}$ rRNA hybridization probes to describe natural communities of methanogens. Appl Environ Microbiol 60: $1232-1240$

Schleper C, Holben W, Klenk HP (1997) Recovery of Crenarchaeotal ribosomal DNA sequences from freshwater lake sediments. Appl Environ Microbiol 63:321-323

Sievers HA, Nowlin WD Jr (1984) The stratification and water masses at Drake Passage. J Geophys Res 89:10489-10514

Stahl DA, Flesher B، Mansfield HR, Montgomery L (1988) Use of phylogenetically based hybridization probes for studies of ruminal microbial ecology. Appl Environ Microbiol 54: $1079-1084$

Stein M, Heywood RB (1994) Antarctic environment physical

Editorial responsibility: Jed Fuhrman,

Los Angeles, California, USA oceanography: the Antarctic peninsula and Southwest Atlantic region of the Southern Ocean. In: ElSayed SZ (ed) Southern ocean ecology. University Press, Cambridge, p 11-24

Ueda T, Suga Y, Matsuguchi T (1995) Molecular phylogenetic analysis of a soil microbial community in a soybean field. Eur J Soil Sci 46:415-421

Vincent WF (1988) Microbial ecosystems of Antarctica. University Press, Cambridge

Ward BB (1984) Combined autoradiography and immunofluorescence for estimation of single cell activity of ammoniumoxidizing bacteria. Limnol Oceanogr 29:402-410

Whitworth $T$ (1980) Zonation and geostrophic flow of the Antarctic Circumpolar Current at Drake Passage. DeepSea Res 27A:497-507

Woese CR, Kandler O, Wheelis ML (1990) Towards a natural system of organisms: proposal for the domains Archaea, Bacteria, and Eucarya. Proc Natl Acad Sci 87 4576-4579

Zheng D, Alm EW, Stahl DA, Raskin L (1996) Characterization of universal smallsubunit rRNA hybridization probes for quantitative molecular microbial ecology studies. Appl Environ Microbiol 62:4504-4513

Submitted: March 25, 1998; Accepted: August 6, 1998 Proofs received from author(s): August 4, 1999 